\title{
Fertilization and Crop Rotation Effects on the Number of Different Groups of Microorganisms
}

\author{
Dragana Stamenov* · Simonida Đurić · Timea Hajnal Jafari · Srđan Šeremešić
}

University of Novi Sad, Faculty of Agriculture, Trg Dositeja Obradovića 8, 21000 Novi Sad, Serbia

\begin{abstract}
Summary: The present study was carried out to investigate the influence of crop rotation and fertilization on the number of different groups of microorganisms. Soil samples were taken from the following treatments: 1 . Monoculture of maize, 2. Maize - wheat (without fertilization), 3. Maize - wheat (with fertilization), 4. Maize - soybean - wheat (with fertilization), 5. Pasture soil, 6. Forest soil under oak, from three depths: 0-10 cm, 10-20 cm, and 20-30 $\mathrm{cm}$ in May and October 2012. Microbiological analyses included the determination of total number of bacteria, number of fungi, actinomycetes, aminoheterotrophs, and azotobacter. The number of investigated groups of microorganisms was higher in May on average. Fertilization did not affect the number of investigated groups of microorganisms. Crop rotation positively affected the total number of bacteria and the number of aminoheterotrophs in soil under maize.

Key words: crop rotation, fertilization, maize, microorganisms, monoculture, soils, wheat
\end{abstract}

\section{Introduction}

Soil is a complex dynamic system which consists of solid, liquid and gaseous phase. Minerals and organic matter are parts of the solid phase (Molnar, 2004). Soil organic matter (SOM) makes only a few percent of the soil total mass. The highest percentage of SOM is humus. Microorganisms play a crucial role in the processes of humification as well as in the cycles of macro and micro nutrients (Cairney, 2000). The microbial biomass also acts as a small but labile reservoir of nutrients that contributes to maintaining long-term agricultural sustainability (Bergstrom et al., 1998).

Soil microorganisms are important to agroecosystems. They are involved in key roles, such as soil aggregate formation, soil humus formation, nutrient cycling, decomposition of various compounds, and other transformations (Wu et al., 2008). Soil microorganisms constitute an active component of the soil organic pool, controlling the breakdown of organic matter and, hence, the release of nutrients and their availability for other organisms (Klironomos et al., 2000). The microbial population in soil is very diverse. Torsvik et al. (1994) calculated the presence of about 6,000 different bacterial genomes per gram of soil by taking the genome size of Escherichia coli as a unit. Microbial biomass is large: in a temperate grassland soil the bacterial and fungal biomass amounted to $1-2$ and $2-5 \mathrm{t}$ per ha, respectively (Killham, 1994). The diversity and

Corresponding author:

dragana.stamenov@polj.uns.ac.rs abundance of microorganisms in the soil far exceeds the diversity of organisms in other ecosystems. The number of microorganisms in different types of soil varies from $10^{6}$ to $10^{9} \mathrm{~g}^{-1}$ dry soil (Whitman et al., 1998). Just one gram of soil can be a habitat for more than 10 trillion microbes, with thousands of different types (RoselloMora \& Amann, 2001).

The composition of the microbial population in the soil is the result of the interaction between soil types, plant types and localization of the microorganism in the rhizosphere (Marschner et al., 2001). Numerous physical and chemical properties of soil, such as carbon and energy sources, mineral nutrients, growth factors, ionic composition, available water, temperature, pressure, air composition, electromagnetic radiation, $\mathrm{pH}$, oxidationreduction potential, surfaces, plant species, interaction between microorganisms, and other factors influence the ecology, activity and population dynamics of microorganisms in soil. These environmental factors can change markedly, and so microhabitats in soil are dynamic systems (Pinton et al., 2001).

The number of certain groups of microorganisms and their enzymatic activity depend on the variability of soil properties as well as the level of anthropogenic influences (Nannipieri et al., 2003). Cinnadurai et al. (2013) showed that fertilizers can affect the function, community structure, and population of soil microorganisms in long-term fertilizer experiments. Fertilization usually strongly favours the accumulation of bacterial residues (Murugan \& Kumar, 2013) and increases soil microbial biomass (Kaur et al., 2005; Ebhin Masto et al., 2006). Giller et al. (1998) reported 
that no relation exists between microbial diversity and decomposition of organic matter, and a reduction in any group of species has little effect on overall soil process because the surviving microorganisms can carry out the decomposition of organic matter. On the other hand, many authors argued that the amount and the type of SOM had a significant impact on the microbial biomass in soil (Grayston et al., 2001). Vast majority of soil microorganisms use organic sources of nutrients and energy. Therefore, soils with higher SOM content have a more diverse and developed microbial population (Bo Liu et al., 2007).

The present study was carried out to investigate the influence of fertilization and crop rotation on the number of different groups of microorganisms.

\section{Material and Methods}

Soil samples for microbiological analyses were taken from the following treatments: 1 . Monoculture of maize (MO), 2. Maize - wheat (without fertilization, NF2), 3. Maize - wheat (fertilization pattern: $120 \mathrm{~kg} / \mathrm{ha} \mathrm{N}$ under maize and $100 \mathrm{~kg} /$ ha $\mathrm{N}$ under wheat, F2), 4. Maize soy - wheat (fertilization pattern: $120 \mathrm{~kg} / \mathrm{ha} \mathrm{N}$ under maize, $100 \mathrm{~kg} /$ ha $\mathrm{N}$ under wheat, microbial fertlizer NS -Nitragin under soy, manure $25 \mathrm{~kg} / \mathrm{ha}, \mathrm{F} 3), 5$. Pasture soil $(\mathrm{P})$, and 6. Forest soil under oak $(\mathrm{F})$. Soil samples were taken from three depths: $0-10 \mathrm{~cm}, 10-20 \mathrm{~cm}$, and $20-30 \mathrm{~cm}$ in May and October of 2012. The experiment was conducted on the field of the Institute of Field and Vegetable Crops, Novi Sad, in Rimski Šančevi.
The total number of bacteria (TNB), the number of aminoheterotrophs (AMH), azotobacter (AZB), actinomycetes (ACT) and fungi (FNG) were determined by the method of agar plates (Trolldenier, 1996). Appropriate nutrient media were used (Hi Media Laboratories Pvt. Limited, Mumbai, India): nutrient agar for the total number of bacteria, synthetic agar for the number of actinomycetes, potato dextrose agar for the number of fungi, meat peptone agar for the number of aminoheterotrophs, and azotobacter medium with mannitol for the number of azotobacter.

The data were statistically processed using STATISTICA 10 software. The significance of the difference between the applied treatments was determined using Fisher's LSD test.

\section{Results and Discussion}

Fertilization is the most common management of agricultural soils. It can influence the biomass, activities, and diversity of the soil microbial community in different ways as different groups of microorganisms could vary in their ability to process the various nutrient forms found in soil (Wei et al., 2008). Microorganisms appear to be very sensitive to management practices such as mineral fertilizer and manure addition (Walsh et al., 2012).

Results of the study are presented in Tables 1 and 2. In this study, fertilization did not positively affect the total number of microorganisms. Statistically significant higher number of microorganisms was recorded in the treatment without fertilization in comparison to other

Table 1. Number of microorganisms in soil in May 2012. (log No/g soil)

\begin{tabular}{|c|c|c|c|c|c|c|}
\hline Treatments & Depth $(\mathrm{cm})$ & $\mathrm{TNB}^{* *}$ & FNG & $\mathrm{ACT}$ & AZB & $\mathrm{AMH}$ \\
\hline \multirow{3}{*}{$\mathrm{MO}^{* * *}$} & $0-10$ & $8.7 \mathrm{e}, \mathrm{f}^{*}$ & $5.2^{\mathrm{a}, \mathrm{b}}$ & $5.3^{a}$ & $3.2^{\mathrm{a}, \mathrm{b}}$ & 8.6 c, d, e, f, g, h \\
\hline & $10-20$ & $8.5^{\mathrm{f}}$ & $4.8 \mathrm{c}, \mathrm{d}, \mathrm{e}, \mathrm{f}$ & $5.0 \mathrm{a}, \mathrm{b}$ & $3.3 \mathrm{a}, \mathrm{b}$ & 8.9 b, c, d, e, f, g \\
\hline & $20-30$ & $7.6 \mathrm{~g}$ & $4.6 \mathrm{~d}, \mathrm{e}, \mathrm{f}, \mathrm{g}$ & $5.1 \mathrm{a}, \mathrm{b}$ & $3.4^{\mathrm{a}}$ & $8.3 \mathrm{f}, \mathrm{g}, \mathrm{h}$ \\
\hline \multirow{3}{*}{$\mathrm{NF} 2$} & $0-10$ & 9.9 a & $5.2 \mathrm{a}, \mathrm{b}$ & $4.8 \mathrm{~b}, \mathrm{c}$ & $3.3^{\mathrm{a}, \mathrm{b}}$ & $8.5 \mathrm{c}, \mathrm{d}, \mathrm{e}, \mathrm{f}, \mathrm{g}, \mathrm{h}$ \\
\hline & $10-20$ & $9.8^{a}$ & $5.2 \mathrm{a}, \mathrm{b}$ & $4.6^{c}$ & $3.3 \mathrm{a}, \mathrm{b}$ & $7.7^{\mathrm{h}}$ \\
\hline & $20-30$ & $9.5^{\mathrm{b}}$ & $5.2^{\mathrm{a}, \mathrm{b}}$ & 4.9 a, b, c & $3.1^{b}$ & $8.5 \mathrm{c}, \mathrm{d}, \mathrm{e}, \mathrm{f}, \mathrm{g}, \mathrm{h}$ \\
\hline \multirow{3}{*}{$\mathrm{F} 2$} & $0-10$ & $9.8^{a}$ & $5.2^{\mathrm{a}, \mathrm{b}}$ & $4.8^{b, c}$ & 3.3 a, b & $10.2^{a}$ \\
\hline & $10-20$ & $9.2 \mathrm{c}, \mathrm{d}$ & $5.2 \mathrm{a}, \mathrm{b}$ & $4.6 \mathrm{c}$ & $3.3 \mathrm{a}, \mathrm{b}$ & $9.1 \mathrm{~b}, \mathrm{c}, \mathrm{d}, \mathrm{e}, \mathrm{f}$ \\
\hline & $20-30$ & $9.2 \mathrm{c}, \mathrm{d}$ & $5.2 \mathrm{a}, \mathrm{b}$ & $4.9 \mathrm{a}, \mathrm{b}, \mathrm{c}$ & $3.4^{a}$ & $9.7 \mathrm{a}, \mathrm{b}$ \\
\hline \multirow{3}{*}{ F3 } & $0-10$ & $9.1 \mathrm{c}, \mathrm{d}$ & $5.3^{a}$ & $5.0 \mathrm{a}, \mathrm{b}$ & $3.3 \mathrm{a}, \mathrm{b}$ & 9.0 b, c, d, e, f, g \\
\hline & $10-20$ & $9.2 \mathrm{c}, \mathrm{d}$ & $5.1 \mathrm{a}, \mathrm{b}, \mathrm{c}$ & $4.9 \mathrm{a}, \mathrm{b}, \mathrm{c}$ & $3.3 \mathrm{a}, \mathrm{b}$ & 9.0 b, c, d, e, f, g \\
\hline & $20-30$ & $8.7 \mathrm{e}, \mathrm{f}$ & $5.1 \mathrm{a}, \mathrm{b}, \mathrm{c}$ & $4.9 \mathrm{a}, \mathrm{b}, \mathrm{c}$ & 3.4 a & $8.4 \mathrm{e}, \mathrm{f}, \mathrm{g}, \mathrm{h}$ \\
\hline \multirow{3}{*}{$\mathrm{P}$} & $0-10$ & $9.4 \mathrm{~b}, \mathrm{c}$ & $5.1 \mathrm{a}, \mathrm{b}, \mathrm{c}$ & $5.0 \mathrm{a}, \mathrm{b}$ & $2.7^{\mathrm{c}}$ & $8.1 \mathrm{e}, \mathrm{g}$ \\
\hline & $10-20$ & $9.3 \mathrm{~b}, \mathrm{c}$ & $5.0^{a, b, c, d}$ & $4.8^{b, c}$ & $2.7^{c}$ & $9.5^{\mathrm{a}, \mathrm{b}, \mathrm{c}}$ \\
\hline & $20-30$ & $8.9 \mathrm{~d}, \mathrm{e}$ & $4.8 \mathrm{c}, \mathrm{d}, \mathrm{e}, \mathrm{f}$ & $4.6^{c}$ & $2.5^{c}$ & $9.7 \mathrm{a}, \mathrm{b}$ \\
\hline \multirow{3}{*}{$\mathrm{F}$} & $0-10$ & $9.3 \mathrm{~b}, \mathrm{c}$ & 4.4 e, f, g & $4.5 \mathrm{c}, \mathrm{d}$ & $0.8 \mathrm{~d}$ & $9.5 \mathrm{a}, \mathrm{b}, \mathrm{c}$ \\
\hline & $10-20$ & $9.1 \mathrm{c}, \mathrm{d}$ & $4.3^{\mathrm{f}, \mathrm{g}}$ & $4.0 \mathrm{e}$ & $0.8 \mathrm{~d}$ & 9.4 a, b, c, d, e \\
\hline & $20-30$ & $8.8 \mathrm{e}, \mathrm{f}$ & $4.2 \mathrm{~g}$ & $4.2 \mathrm{~d}, \mathrm{e}$ & $0.8^{\mathrm{d}}$ & $9.3 \mathrm{a}, \mathrm{b}, \mathrm{c}, \mathrm{d}, \mathrm{e}$ \\
\hline
\end{tabular}

* The different letter above the number indicates significant difference at $\mathrm{P}<0.05$ according to Fisher`s test

**AMH -aminoheterotrophs; AZB - Azotobacter; TNB- total number; ACT- actinomycetes; FNG- fungi;

*** MO-monoculture of maize, NF2- maize-wheat (without fertilization), F2- maize-wheat (with fertilization), F3- maize-soy-wheat (with fertilization), P- pasture soil, F- forest soil under oak. 
investigated treatments. Results analysis showed that particularly the microbial biomass of fungi and actinomycetes in soil was not affected by fertilization. Also, statistical analysis showed that fertilization did not exert a significant influence on the number of free-living nitrogen fixing bacterium Azotobacter sp. Its number in forest soil samples was less abundant which can be explained by low soil pH. Đurić et al. (2004) studied the same treatments and concluded that the highest microbial activity was determined after maize cultivation in system with three crops without fertilization. Šeremešić (2012) also found that the treatments without fertilization had much higher number of fungi in comparison to the treatments with fertilization. Contrary to our results, the change of bacterial community structure by fertilizer had been observed in several long-term field experiments (Sun et al., 2004; Hatch et al., 2007). Similarly, in Ahmad et al. (2014), fertilizer treatments significantly $(\mathrm{P}<0.01)$ increased microbial biomass nitrogen $(\mathrm{MBN})$ and microbial biomass carbon (MBC) with the maximum increase in mixed application of farmyard manure and mineral fertilizers treatment, both in surface and sub-surface soil. The addition of organic and inorganic fertilizers in an integrated form increased soil organic matter content that provides a carbon source and other nutrients for microbes (Courtney \& Mullen, 2008) and altered the biochemical properties of the soil by increasing potentially mineralizable $\mathrm{N}$ and microbial biomass $\mathrm{C}$ and $\mathrm{N}$ (Monaco et al., 2008). Also, an increase in the enzyme activity was also observed after addition of either NPK fertilizer or farmyard manure in a long-term study (Kandeler et al., 1999).

In this study, the lack of effect of the fertilizers application on the number of microorganisms can be explained by the short time period of the experiment. According to Crecchio et al. (2001), organic and inorganic fertilizers are primarily used to increase crop yield, and in short-term fertilizer experiments, they have no significant effect on microbial community.

Crop rotation had a stimulatory effect on the total number of microorganisms. There are studies reporting higher variability in microbial communities in response to different crop rotations (Fox \& MacDonald, 2003; Liu et al., 2008). Furthermore, our study showed that the introduction of crop rotation with different levels of fertilization positively affected the number of aminoheterotrophs in soil under maize during vegetation period. Our results are in agreement with numerous results (O’Donnell et al., 2001; Johnson et al., 2003). Also, Kandeler et al. (1999) suggested the favourable effects of organic manure application and crop rotation on soil enzyme activities.

The number of investigated groups of microorganisms varied with the depth of sampling. The highest total number of microorganisms was determined under maize monoculture at the depth from 20 to $30 \mathrm{~cm}$ in October. Number of fungi decreased with the increase of soil depth in treatments with maize monoculture, pasture and forest soil. On average, number of actinomycetes and aminoheterotrophs also decreased in deeper soil layers. Statistically significant

Table 2. Number of microorganisms in soil in October 2012 (log No/g soil)

\begin{tabular}{|c|c|c|c|c|c|c|}
\hline Treatments & Depth $(\mathrm{cm})$ & $\mathrm{TNB}^{* *}$ & FNG & ACT & AZB & $\mathrm{AMH}$ \\
\hline \multirow{3}{*}{$\mathrm{MO}^{* * *}$} & $0-10$ & $7.3 \mathrm{e}, \mathrm{f} *$ & $5.1 \mathrm{a}, \mathrm{b}$ & $4.6 \mathrm{c}, \mathrm{d}, \mathrm{e}$ & $3.0 \mathrm{a}, \mathrm{b}$ & $7.3 \mathrm{f}, \mathrm{g}$ \\
\hline & $10-20$ & $7.3 \mathrm{e}, \mathrm{f}$ & $5.3^{a}$ & $4.5^{\mathrm{d}, \mathrm{e}}$ & $2,9 \mathrm{~b}$ & $7.3 \mathrm{f}, \mathrm{g}$ \\
\hline & $20-30$ & $9.5^{\mathrm{a}, \mathrm{b}}$ & $3.9 \mathrm{~d}, \mathrm{e}, \mathrm{f}$ & $4.5 \mathrm{~d}, \mathrm{e}$ & 3.0 a, b & 8.9 a, b, c, d, e \\
\hline \multirow{3}{*}{ NF2 } & $0-10$ & $9.2 \mathrm{a}, \mathrm{b}, \mathrm{c}, \mathrm{d}$ & $5.0 \mathrm{a}, \mathrm{b}$ & $4.1 \mathrm{e}$ & $2.9 \mathrm{~b}$ & $9.4 \mathrm{a}, \mathrm{b}$ \\
\hline & $10-20$ & $9.1 \mathrm{a}, \mathrm{b}, \mathrm{c}, \mathrm{d}$ & $4.7 \mathrm{a}, \mathrm{b}, \mathrm{c}, \mathrm{d}$ & $4.5^{\mathrm{d}, \mathrm{e}}$ & $3.0 \mathrm{a}, \mathrm{b}$ & $9.4 \mathrm{a}, \mathrm{b}$ \\
\hline & $20-30$ & $9.1 \mathrm{a}, \mathrm{b}, \mathrm{c}, \mathrm{d}$ & $4.1 \mathrm{c}, \mathrm{d}, \mathrm{e}, \mathrm{f}$ & $4.1^{\mathrm{e}}$ & $3.2^{\mathrm{a}, \mathrm{b}}$ & $9.6^{a}$ \\
\hline \multirow{3}{*}{$\mathrm{F} 2$} & $0-10$ & $8.2 \mathrm{c}, \mathrm{d}, \mathrm{e}$ & $4.9 \mathrm{a}, \mathrm{b}$ & $5.3 \mathrm{a}, \mathrm{b}, \mathrm{c}$ & $3.2^{\mathrm{a}, \mathrm{b}}$ & $9.0^{a, b, c, d}$ \\
\hline & $10-20$ & $7.0 \mathrm{f}$ & $4.6 \mathrm{a}, \mathrm{b}, \mathrm{c}, \mathrm{d}$ & $5.1 \mathrm{a}, \mathrm{b}, \mathrm{c}, \mathrm{d}$ & $3.0 \mathrm{a}, \mathrm{b}$ & $8.1 \mathrm{~d}, \mathrm{e}, \mathrm{f}$ \\
\hline & $20-30$ & $8.1 \mathrm{~d}, \mathrm{e}, \mathrm{f}$ & $4.9 \mathrm{a}, \mathrm{b}$ & $4.7 \mathrm{~b}, \mathrm{c}, \mathrm{d}, \mathrm{e}$ & $3.0^{\mathrm{a}, \mathrm{b}}$ & $8.6^{b, c, d, e}$ \\
\hline \multirow{3}{*}{ F3 } & $0-10$ & $7.3 \mathrm{e}, \mathrm{f}$ & $3.7 \mathrm{e}, \mathrm{f}$ & $5.1 \mathrm{a}, \mathrm{b}, \mathrm{c}, \mathrm{d}$ & $3.2^{\mathrm{a}, \mathrm{b}}$ & $9.4^{\mathrm{a}, \mathrm{b}}$ \\
\hline & $10-20$ & $7.3 \mathrm{e}, \mathrm{f}$ & $4,3 \mathrm{~b}, \mathrm{c}, \mathrm{d}, \mathrm{e}$ & $5.1 \mathrm{a}, \mathrm{b}, \mathrm{c}, \mathrm{d}$ & $3.3^{a}$ & $9.2^{a, b, c}$ \\
\hline & $20-30$ & $7.3 \mathrm{e}, \mathrm{f}$ & $4.0 \mathrm{c}, \mathrm{d}, \mathrm{e}, \mathrm{f}$ & $4.5 \mathrm{~d}, \mathrm{e}$ & $3.3 \mathrm{a}$ & $9.0 \mathrm{a}, \mathrm{b}, \mathrm{c}, \mathrm{d}$ \\
\hline \multirow{3}{*}{$\mathrm{P}$} & $0-10$ & 8.6 b, c, d & $5.0 \mathrm{a}, \mathrm{b}$ & $5.1 \mathrm{a}, \mathrm{b}, \mathrm{c}, \mathrm{d}$ & $1.9^{c}$ & $8.0 \mathrm{f}, \mathrm{g}$ \\
\hline & $10-20$ & $8.1 \mathrm{~d}, \mathrm{e}, \mathrm{f}$ & $4.6 \mathrm{a}, \mathrm{b}, \mathrm{c}, \mathrm{d}$ & $4.5^{\mathrm{d}, \mathrm{e}}$ & $1.9^{\mathrm{c}}$ & $8.2^{\mathrm{c}, \mathrm{d}, \mathrm{e}, \mathrm{f}}$ \\
\hline & $20-30$ & $8.3 \mathrm{c}, \mathrm{d}, \mathrm{e}$ & 4.8 a, b, c & $4.6 \mathrm{c}, \mathrm{d}, \mathrm{e}$ & $1.0 \mathrm{~d}$ & $7.1 \mathrm{~g}$ \\
\hline \multirow{3}{*}{$\mathrm{F}$} & $0-10$ & $9.3 \mathrm{a}, \mathrm{b}, \mathrm{c}$ & $4.0 \mathrm{c}, \mathrm{d}, \mathrm{e}, \mathrm{f}$ & $5.4 \mathrm{a}, \mathrm{b}$ & $0.7 \mathrm{~d}$ & $8.5 \mathrm{~b}, \mathrm{c}, \mathrm{d}, \mathrm{e}$ \\
\hline & $10-20$ & $9.4^{\mathrm{a}, \mathrm{b}}$ & $4.1 \mathrm{c}, \mathrm{d}, \mathrm{e}, \mathrm{f}$ & $5.5^{a}$ & $0.7^{d}$ & 8.9 a, b, c, d, e \\
\hline & $20-30$ & $9.4 \mathrm{a}, \mathrm{b}$ & $3.3 \mathrm{f}$ & $4.9 \mathrm{a}, \mathrm{b}, \mathrm{c}, \mathrm{d}$ & $0.7 \mathrm{~d}$ & $9.2^{\mathrm{a}, \mathrm{b}, \mathrm{c}}$ \\
\hline
\end{tabular}

* The different letter above the number indicates significant difference at $\mathrm{P}<0.05$ according to Fisher`s test

**AMH -aminoheterotrophs; AZB - Azotobacter; TNB- total number; ACT- actinomycetes; FNG- fungi;

*** MO-monoculture of maize, NF2- maize-wheat (without fertilization), F2- maize-wheat (with fertilization), F3- maize-soy-wheat (with fertilization), P- pasture soil, F- forest soil under oak. 
increases were observed only for the number of aminoheterotrophs in pasture soil in May and under maize monoculture in October. The number of Azotobacter varied with the depth, but those differences were not statistically important. The decline in bacterial number with increasing depth observed in this study agrees with that observed by Fierer et al. (2003). Also, in Ekelund et al. (2001), bacterial numbers and biomass in the profiles declined from about $20 \%$ to $1 \%$ from the top to the bottom. According to Fierer et al. (2003), soil resource availability is the main factor responsible for the changes in microbial community composition through the soil profiles. Soil $\mathrm{pH}$, temperature, and texture are not likely to cause differentiation of microbial communities within the top $50 \mathrm{~cm}$ of profiles, yet soil $\mathrm{pH}$, soil texture, and average annual soil temperatures are relatively constant within this range. This could be an explanation for the small variation in the number of the microorganisms in the different soil depths in this study.

\section{Conclusions}

The results of the present study show that the number of investigated groups of microorganisms in May was, on average higher in relation to its number in October. Crop rotation positively affected TNB in soil under maize, especially in May, while fertilization treatments did not influence significantly. Statistically significant changes in the number of ACT and FNG were not achieved in maize rhizospheric soil. Fertilization did not have a significant influence on the number of Azotobacter sp. Crop rotation affected positively the number of AMN. The number of all investigated groups of microorganisms decreased with the increase of soil depth though those changes were not in the range of statistical significance.

\section{References}

Ahmad, W., Farmanullah Zahir, S., Muhammad, J., \& Kawsar Ali, S. (2014). Recovery of organic fertility in degraded soil through fertilization and crop rotation. J. Saudi Society of Agric. Sci., 13, 9299.

Bergstrom, D. W., Monreal, C. M., \& King, D. J. (1998). Sensitivity of soil enzyme activities to conservation practices, Soil Sci Soc Am J, 62, 1286-1295.

Bo Liu, M. L. Gumpertz, H. Shuijin, \& Ristaino, J. B. (2007). Longterm effects of organic and synthetic soil fertility amendments on soil microbial communities and the development of southern blight. Soil Bio Biochem, 3, 2302-2316.

Cairney, J. W. G. (2000). Evolution of mycorriza systems, Naturwisenschaften, 87, 467-475.

Cinnadurai, C., Gopalaswamy, G., \& Balachandar, D. (2013). Diversity of cultivable Azotobacter in the semi-arid alfisol receiving longterm organic and inorganic nutrient amendments. Ann Microbiol, l 63, 1397-1404.

Courtney, R. G., \& Mullen, G. J. (2008). Soil quality and barley growth as influenced by the land application of two compost types. Bioresource Technol, 99(8), 2913-2918.

Crecchio, C., Curci, M., Mininni, R., Ricciuti, P., \& Ruggiero, P. (2001). Shortterm effects of municipal solid waste compost amendments on soil carbon and nitrogen content, some enzyme activities and genetic diversity. Biol Fertil Soils, 34, 311-318.
Đurić, S., Jarak, M., Šeremešić, S., \& Milošev, D. (2004). Effects of crop rotation and fertilization on microbiological activity in soil. Proceedings of the ESNA XXXIV Annual meeting, pp. 128-131.

Ebhin Masto, R., Chhonkar, P. K., Singh, D., \& Patra, A. K. (2006). Changes in soil biological and biochemical characteristics in a long-term field trial on a sub-tropical inceptisol. Soil Biol Biochem, 38, 1577-1582.

Ekelund, F., Roon, R., \& Christensen, S. (2001). Distribution with depth of protozoa, bacteria and fungi in soil profiles from three Danish forest sites, Soil Biol Biochem, 33, 475-481.

Fierer, N., Joshua, P. S., Patricia A. H. (2003). Variations in microbial community composition through two soil depth profiles. Soil Biol Biochem, 35, 167-176.

Fox, C. A., \& MacDonald, K. B. (2003). Challenges related to soil biodiversity research in agroecosystems-issues within the context of scale of observation. Can J Soil Sci, 83, 231-244.

Giller, K. E., Witter, E., \& McGrath, S. P. (1998). Toxicity of heavy metals to microorganisms and microbial processes in agricultural soils: a review. Soil Biol Biochem, 30, 1389-1414.

Grayston, S. J., Griffith, G. S., Mawdsley, J. L., Campbell, C. D., Bardget, R. D. (2001). Accounting for variability in soil microbial communities of temperate upland grassland ecosystem. Soil Bio. Biochem, 33, 533-551.

Hatch, D. J., Goodlass, G., \& Shepherd, M. A. (2007). The effect of cutting, mulching and applications of farm yard manure on nitrogen fixation in a red clover grass sward. Biores Technol, 98, 3243-3248.

Johnson, M. J., Lee, K. Y., \& Scow, K. M. (2003). DNA fingerprinting reveals links among agricultural crops, soil properties, and the composition of soil microbial communities. Geoderma, 114, 279303.

Kandeler, E., Luxhoi, J., Tscherko, D., \& Magid, J. (1999). Xylanase, invertase and protease at the soil-litter interface of a loamy sand. Soil Biology Biochem, 31, 1171-1179.

Kaur, K., Kapoor, K. K., \& Gupta, A. P. (2005). Impact of organic manures with and without mineral fertilizers on soil chemical and biological properties under tropical conditions. J Plant Nutr Soil Sci, 168, 117-122.

Killham, K. (1994). Soil Ecology. Cambridge: Cambridge University Press.

Klironomos, J. N., McCune, J., Hart, M., \& Neville, J. (2000). The influence of arbuscular mycorrhizae on the relationship between plant diversity and productivity, Ecol Letters, 3, 137-141.

Liu, A., Hamel, C., Spedding, T., Zhang, T. Q., Mongeau, R., Lamarre, G. R., \& Tremblay, G. (2008). Soil microbial carbon and phosphorus as influenced by phosphorus fertilization and tillage in a maize-soybean rotation in south-western Quebec. Can J Soil Sci, 88, 21-30.

Marschner, P., Yang, C. H., Lieberei, R., \& Crowley, D. E. (2001). Soil and plant specific effect on bacterial community composition in the rhizosfere, Soil Bio Biochem, 33, 1437-1445.

Molnar, I. (2004). Opšte ratarstıo. Novi Sad: University of Novi Sad, Faculty of Agriculture.

Monaco, S., Hatch Sacco, D. J., Bertora, D., \& Grignani, C. (2008). Changes in chemical and biochemical soil properties induced by 11 year repeated additions of different organic materials in maizebased forage systems. Soil Bio Biochem, 40, 608-615.

Murugan, R., \& Kumar, S. (2013). Influence of long-term fertilisation and crop rotation on changes in fungal and bacterial residues in a tropical ricefield soil. Biol Fertil Soils, 49, 847-856.

Nannipieri, P., Ascher, J., Ceccherini, M. T., Landi, L., Pietramellara, G., \& Renella, G. (2003). Microbial diversity and soil functions, Eur J Soil Sci, 54, 665-670.

O’Donnell, A. G., Seasman, M., \& Macraem A. (2001). Plants and fertilisers as drivers of change in microbial community structure. Plant Soil, 232, 135-145.

Pinton, R., Varanini, Z., \& Nannipieri, P. (2001). The rhizosphere: biochemistry and organic substances at the soil-plant interface. New York: Marcel Dekker.

Rosello-Mora, R., \& Amann, R. (2001). The species concept for procaryotes. FEMS Microbiological review, 25, 39-67.

Šeremešić, S. (2012). Uticaj sistema ratarenja na svojstva organske materije cernozema. Doctoral dissertation. Novi Sad: University of Novi Sad, Faculty of Agriculture. 
Sun, H. Y., Deng, S. P., \& Raun, W. R. (2004). Bacterial community structure and diversity in a century-old manure-treated agroecosystem. Appl Environ Microbiol, 70, 5868-5874.

Torsvik, V. L., Goksoyr, J., Daae, F. L., Sørheim, R., Michalsen, J., \& Salte, K. (1994). Use of DNA analysis to determine the diversity of microbial communities. In: K. Ritz, J. Dighton \& K.E. Giller (Eds.), Beyond the biomass: compositional and functional analysis of soil microbial communities, pp. 39-48. John Wiley \& Sons, New York.

Trolldenier, G. (1996). Plate Count Technique. In: F. Schinner, E. Kandeler, R. Ohlinger, R. Margesin (Eds.), Methods in soil biology (pp. 20-26). Berlin Heidelberg: Springer-Verlag.

Walsh, J. J., Rousk, J., Edwards-Jones, G., Jones, D. L., \& Williams, A. P. (2012). Fungal and bacterial growth following the application of slurry and anaerobic digestate of livestock manure to temperate pasture soils. Biol Fertil Soils, 48, 889-897.

Wei, D., Yang, Q., Zhang, J. Z., Wang, S., Chen, X. L., Zhang, X. L., \& Li, W. Q. (2008). Bacterial community structure and diversity in a black soil as affected by long-term fertilization. Pedosphere, 18, 582-592.

Whitman, W. B., Coleman, D. C., \& Wiebe, W. J. (1998). Procaryote the unseen majority. Proceedings of the National Academy of Sciences of the USA, 95, 6578-6583.

Wu, T., Chellemi, D. O., Graham, J. H., \& Rosskopf, E. N. (2008). Assessment of fungal communities in soil and tomato roots subjected to diverse land and crop management systems. Soil Biol Biochem, 40, 1967-1970.

\section{Uticaj đubrenja i plodoreda na brojnost mikroorganizama u zemljištu \\ Dragana Stamenov · Simonida Đurić · Timea Hajnal Jafari · Srđan Šeremešić}

Sažetak: Ova istraživanja su sprovedena da bi se ispitao uticaj plodoreda i đubrenja useva na brojnost različitih grupa mikroorganizama. Uzorci zemljišta su uzeti iz sledećeg tretmana: 1. monokultura kukuruza, 2. kukuruz - pšenica (bez đubrenja), 3. kukuruz - pšenica (sa đubrenjem) 4. kukuruz - soja - pšenica (sa đubrenjem), 5. zemljište pašnjaka, 6. šumsko zemljište pod hrastom, iz tri dubine: $0-10 \mathrm{~cm}, 10-20 \mathrm{~cm}$ i $20-30 \mathrm{~cm}$, u maju i oktobru 2012. godine. Mikrobiološkim analizama je određen ukupan broj bakterija, broj gljiva, aktinomiceta, aminoheterotrofa i brojnost Azotobacter-a. Broj ispitivanih grupa mikroorganizama je u proseku bio veći u maju. Đubrenje nije izazvalo statistički značajne promene u brojnosti ispitivanih grupa mikroorganizama. Plodored je pozitivno uticao na ukupan broj bakterija i broj aminoheterotrofa u zemlijistu pod usevom kukuruza.

Ključne reči: đubrenje, kukuruz, mikroorganizmi, monokultura, plodored, pšenica, zemljište 